\title{
The Paradox of the Presidency: The Difference a President makes in Institutional Functioning at Three Community Colleges
}

\author{
JOHN S. LEVIN ${ }^{\star}$
}

\begin{abstract}
Do presidents make a difference? Presidential impact on colleges and universities has been called into question for decades. Most recently, there is evidence to suggest that institutional functioning may not be affected by who presidents are or by what presidents do (Birnbaum, 1989). Such questioning fits within the mainstream of thinking on the presidency at higher education institutions. This thinking conveys a dualism of perceptions about presidents (Benezet et al., 1981). On the one hand, presidents are seen to have both power and authority to direct their institutions; on the other hand, presidents are seen has having limited control over their institutions. Twenty-four governing board members at three Canadian community colleges were interviewed to determine whether and to what extent presidents are seen to make a difference in institutional functioning.
\end{abstract}

This study concludes that from the perspective of board members, presidents do make a difference in institutional functioning. Presidential impact can be seen in public and government perceptions of the college, in institutional decision-making, and in the preservation of college philosophy. Furthermore, the president is the educational leader, not as a determiner of educational programs or teaching performance, but rather as the communicator of institutional orientations and actions.

\section{Résumé}

Est-ce que les présidents, par leurs contributions personelles, apportent des modications significatives au fonctionnement des institutions? Pendant des décennies, l'impact présidentiel sur les collèges et les universités a été l'objet de nombreuses contestations. Actuellement, il existe des preuves qui suggèrent que le fonctionnement des institutions ne serait influencé ni par la position du

* North Island College, Port Alberni, B.C. 
président ni par ses actions (Birnbaum, 1989). De telles contestations ont bien leur place dans le courant dominant des opinions concernant la présidence dans les institutions d'education supérieure. C'est cette ligne de pensée qui explique le dualisme de perceptions, vis-à-vis les présidents. D'une part, les présidents sont vus comme éducateurs ayant et le pouvoir et l'autorité nécessaires pour l'administration de leurs institutions; d'autre part, ils sont envisagés comme éducateurs n'ayant qu'un contrôle restreint de leurs institutions.

Nous avons interviewé vingt-quatre membres du conseil d'administration dans trois collèges communautaires. Ils ont également servi de sources de données et d'observations afin de déterminer si les présidents apportent des contributions significatives au fonctionnement des institutions.

Cette étude conclut que du point de vue des membres du conseil, les présidents contribuent de façon significative au fonctionnement des institutions. L'impact du président se laisse voir dans les perceptions publiques et gouvernementales du collège, dans le processus démocratique par lequel les décisions sont prises aussi bien que dans la conservation de la philosophie du collège. De plus le président est vu comme un chef educatif, non pas dans le rôle de celui qui détermine les programmes académiques ou la performance des professeurs, mais plutôt dans le rôle de celui qui communique aux autres les orientations et les actions de l'institution.

Presidential impact on colleges and universities has been called into question for decades. There is recent evidence that institutional functioning may not be affected by who presidents are or by what presidents do (Birnbaum, 1989). Yet appeals for improved leadership of colleges and universities can be heard from practitioners and scholars alike. Just as the literature on organizational leadership is divided on the basis of the effectiveness of leaders (Pfeffer, 1981), so too is there division in the literature on the presidents of academic institutions. This literature indicates that two patterns of thought dominate thinking about the presidency (Benezet et al., 1981). The first pattern suggests that presidents are products of a stream of forces outside their personal control, and that they demonstrate, in what they do, their limited control over their institutions. The second pattern suggests that presidents have both power and authority to control their institutions and to direct institutional functioning. Furthermore, there are many conflicting and contradictory thoughts on what a president does or should do (Kauffman, 1980). In the main, views on presidents and the presidency in higher education focus on two main themes: expectations of the presidency and constraints and limitations on the president. 
Both themes support a scholarly following. Those who champion the theme of expectations generally adhere to the position that the president has a positive effect on organizational functioning (e.g., Dodds, 1962; Kauffman, 1980; Fisher, 1984, Vaughan, 1986). Those who are associated with the theme of constraint and limitation suggest that the president has little or no effect on organizational functioning (e.g., Stoke, 1959; Mortimer \& McConnnell, 1978; Cohen \& March, 1986; Kerr \& Gade, 1986). A third option, however, can be seen in those who embrace both themes (e.g., Dennison \& Gallagher, 1986; Birnbaum, 1988), suggesting presidential influence and limitations. The contrasting and divergent views of the president have by now acquired acceptability by scholars as a single but ambivalent conception. Thus, the suggestion that institutional functioning may not be a affected by who presidents are or what they do (Birnbaum, 1989) fits within the mainstream of thinking on the presidency at higher education institutions. Such suggestions and conclusions do not, however, clearly indicate an unambiguous relationship between presidents and institutional functioning. Scholars do not know with confidence the connection between what a president does and institutional performance.

Scholarship on presidential impact can be seen to be derived from research on targeted groups. Birnbaum (1989) samples faculty at colleges and universities. Vaughan (1986) samples presidents at community colleges. Others (e.g., Kauffman, 1980; Fisher, 1984) draw upon their own personal experiences as presidents of academic institutions.

How do those who see the president up close perceive the impact of the president? How do those who are not bureaucratic subordinates judge the chief executive officer? If the sources of data are different from those found in other studies which judge the impact of the president - based, for example, on faculty perceptions (e.g., Birnbaum, 1989) — are other observations forthcoming?

\section{The Study}

Twenty-four governing board members at three Canadian community colleges in the province of British Columbia were interviewed and gave their perceptions of whether and to what extent presidents make a difference in institutional functioning. All three British Columbia colleges were public postsecondary educational institutions established by the provincial government, funded by government and governed under provincial legislation. All were comprehensive community colleges (Dennison \& Gallagher, 1986) created in the late 1960s or early 1970s. 
The three colleges had numerous similar features. They had student populations of approximately 4000 . They offered a wide range of services, including programs in vocational, career, and university transfer education. They provided their respective communities with an extensive array of non-credit courses; and they provided their students with developmental and educational services such as personal counselling and remedial education.

The governing board members were government appointees. Board size ranged in number from a low of seven to a high of nine members. Duration of service to each college by board members varied: several board members at each college were board members in excess of five years; and at each college there were members with less than two years of service. Gender representation was evident at all three colleges, although males outnumbered females by a ratio of approximately 3 or 4 to 1 . At two of the colleges, there was a female board chairperson, and at the one college with a male board chairperson, the vice-chairperson was female.

Presidents were all appointed by the governing board, and all presidents were longtime employees of the college, serving previously in other administrative capacities. All presidents were male, middle-aged, and in their first presidential positions, having occupied that position for at least two years.

Collected in 1988, the data, derived from one and a half hour semi-structured interviews with individual board members, as well as with the three presidents, were organized into summaries for each individual respondent. These respondents subsequently verified the accuracy of the summaries. Interview questions derived from a review of the literature on presidents and governing boards were developed and pilot-tested with both board members and presidents from colleges not involved in this study. The substance of these questions concerned those activities which board and president would carry out together, such as policy development, budget development and approval, educational planning, and the creation of a public image for the college. Other questions put to board members dealt with the personal association of the two parties. The questions were structured so that responses given were descriptions of behaviours, and assessments of the outcomes of the behaviours. Developed questions were used for a larger study which sought to describe the relationship which existed between the two parties (Levin, 1989). Within the context of this larger study, board members described the personal qualities of the presidents when asked, "What do you like about your relationship with the president?" Subsequently, board members described and assessed the effects of the personal qualities of the president on the institution. Presidents, in a similar way, were asked what 
they liked about their relationship with board members. Qualitative analysis of these summaries (Miles \& Huberman, 1984) was directed at determining how board members perceived the impact of the president upon their institutions. Patterns and themes were identified and frequencies of behaviours and actions were noted. Data were analysed interpretively (on the basis of individual respondents and individual colleges) and comparatively (on the basis of all three colleges). Data from the presidents were used to compare with that from board members, to provide clarification, contrast, or confirmation.

The three colleges were given the fictitious names of Appletree College, Oak College, and Cedar College in order to maintain the anonymity of the institutions and the respondents. This anonymity was a prerequisite condition of data collection at the outset of the study.

While it can be argued that the sample group itself, board members, would engender responses which are positively biased, a companion argument for negative or positive bias could be made for any study which targets specific groups, such as faculty (Birnbaum, 1989). The use of board members in this study had two main purposes: first, to balance the research on presidential impact by choosing a different source from more frequently used ones; and second, by exploring a sample group which may have knowledge of the president not revealed to other parties. Wood (1985) is one of the few scholars who examines the board-president relationship, refuting the commonly held view that board members are both the apologists for the president and allies of the president. Instead, she notes that there can be tensions in the relationship and negative views held by board members toward the president.

\section{Interpretative Analysis: Three Colleges}

\section{Appletree College}

At Appletree College, the president was characterized through descriptions of his interpersonal skills. (All quotations below and further quotations in this section were derived from interview summaries from respondents at Appletree College.)

The president is a supportive, nurturing individual. This supplies him with support as well. This personal rapport he has helps him in difficult times. His personality has a positive effect on the relationship. Personal trust is evident.

I find him to be...very honest and open...hardworking and capable. The president is compassionate... 
Those who know the president have positive responses to him. I admire the president as a person; I like his personal aims and goals...He's open...

The president is a man of principle and high ideals. He is a civilized man. I appreciate him as a human being.

I respect the president. He is honest and hardworking.

The personality of the president plays a great role. The president's interpersonal skills are a benefit to the institution.

While two of the nine board members, who are not quoted above, had partially negative comments to make about the president, the overwhelming majority of board members lauded the personal qualities of the president. These qualities included honesty, integrity, diligence, compassion, and they suggested as well an individual who had appealing ideas and who attracted followers.

The president had made the most obvious impact on the institution through his effects upon two major groups - the local communities and government. At the beginning of his presidency, the Appletree College president inherited an institution mired in public controversy, deemed to be the responsibility of the former president. College interest groups (government, the local community, college employees, and the board) were all affected by what was referred to as a financial scandal, associated with the former president. As board members noted, the current president, through his actions, improved the image of the college in the view of the local community and government. The president altered the administrative structure to lessen presidential control; involved himself in local community organizations and activities; and developed a close personal association with the Minister of Advanced Education and Job Training, the elected government official with the highest authority in governing the provincial colleges. According to board members, the actions of the president had salient effects upon the college.

The government minister is personally supportive of the college.

Over the past two years the media have become more supportive of the college.

This president...has repaired a poor image.

We have a good image in the community.

Board members, in the majority, viewed the president of Appletree College as effective in carrying out his many duties, especially in the areas of promoting 
a positive public image for the college and in achieving government support for the college. The president had both administrative talent in securing support from various groups including board members, community members, and government officials. While some board members saw him as an educational leader, the majority viewed him as the administrative or executive leader of the college.

\section{Oak College}

At Oak College, the president was characterized through both his personal qualities and his connection with the institution. (All quotations below and further quotations in this section were derived from interview summaries from respondents at Oak College.)

I have tremendous respect for his abilities.

The president is a very creative guy...The president personalizes the mission of the college.

He is personally affected by problems in the college...His personality is compatible with a participatory style of management.

I don't think he is making decisions on educational planning. Here we have participatory management...I greatly admire his capabilities, energies, volume of work his is able to cope with...

The president's love of the institution is transferred.

The college is fortunate to have a president with the right personality...He has a sense of justice...

The president does not dictate...He is approachable.

He is a very sincere, honest person...He is not able to separate his role from...faculty.

On the one hand, board members recognized and acknowledged the personal traits of the president, including his creativity, his energy, and his personal values. On the other hand, board members connected the president with the institution and suggested that the operational style of the college (participatory management), the mission of the college, and organizational climate in the college at a particular time (e.g., during labour disputes) were inseparable from the president. 
The president at Oak College had most pronounced influence on two areas - policy development (and its accompanying processes), and the image of the college in the community. The president was viewed as the leader in the area of policy development, lauded for his knowledge and his communicaiion skills and his ability to initiate actions and to motivate others. Board members noted that Oak College not only had developed beneficial policies but had also maintained its approach to decision-making, which was deemed to be participatory, groupfocussed, and consensual. The president both sustained and promoted this style of decision-making, which involved an elaborate committee structure, including faculty, staff, students, administrators, and board members.

The president's actions, his motivating of board members, his interactions with community groups and individuals, and his overseeing of college ventures in the community, were viewed as responsible for a positive perception of the college by the community. Specific results of the president's actions in the public promotion of the college, however, were not apparent. Most obvious was the impression by board members that the community and the public judged the college in a positive light and that the college involved community members in decision-making, consistent with its style of management and governance. The role of the college in the community was viewed by all interest groups, according to board members, as consistent with community needs.

The college has achieved a very positive public image perception.

When policy comes to the board it has been well thought-out.

It is the people's place.

...[E]veryone feels a part of the policy. They have a sense of responsibility toward policy.

...[W]e meet the changing community needs.

Policy comes up through the institution and involves many people.

We have a strong administrative group, not a one man show. This strengthens the institution. We have the strength of a united front.

We get the programs faculty want. I think it's good.

Board members at Oak College viewed the president as effective in providing administrative leadership to the college and as well in furthering the goals of 
the college. The college, according to board members, was a closely knit group, including college employees, students, and members of the local communities. The president served to hold this group together and to sustain the values (or ideology) of the college which were embedded in policies, college publications, and collective agreements. Furthermore, by his example, the president motivated others to participate in college activities and in the managerial and governing actions required to carry out college functions.

\section{Cedar College}

At Cedar College, the president was characterized by his skills as an administrative leader who directs the operations of the college. (All quotations below and further quotations in this section were derived from interview summaries from respondents at Cedar College.)

If the president wants a particular initiative, it is likely the college will do it; if the president doesn't want an initiative then it will likely not happen.

The president is a powerful figure.

We know the president is well-intended.

Within the institution, the president is seen as very influential.

The president is very capable. He is in a position of power.

While board members indicated that they trusted the president, that they respected the president's intellectual and political skills, and that they were confident about his intentions, they left little doubt that the president was a powerful figure. His power was not just as a consequence of the office of the president but in large part, for the board members at Cedar College, tied to the president's skills as negotiator, his leadership actions as guider and director of institutional operations, and his intelligence.

The president was seen to have the most pronounced influence upon college policy and on the public image of the college. In policy development, the president was viewed as guiding the process, providing information, indicating action alternatives and consequences to board members, and being accessible to board members. As a consequence of the president's leadership with policy development, the policies approved by the board were viewed as appropriate for college operations. Furthermore, and most importantly, in the description of the president, policies were not seen to stand in the way of tradition at Cedar College. 
The public image of the college, as a specific kind of community college, was fashioned under the direction of the president. This image was viewed as consistent with the beliefs of college employees about their college. The pervasiveness of these beliefs can be seen in how college participants acquired them, as amplified in the words of one board member.

The college has a specific image, and board members grow into the image of the college. As a board member...you begin to recognize what the image is...Board members start to believe in their college's own reputation. This becomes a selffulfilling prophecy.

The president's actions led to the maintenance of the college's image, primarily adhered to by college employees, including faculty, staff, and administrators, and by college board members. This image, as one board member pointed out, was largely determined by the type of faculty employed by the college. The president, who was viewed by board members as the conveyor of faculty perceptions and decisions, maintained and promoted the values of the faculty as a whole. The president noted that he was "aware of the aspirations and the culture of the institution." While there was, as one board member noted, "general acceptance of the president's view of the college," not all board members agreed with the president. Nonetheless, the president was able to perpetuate this image and the board accepted his actions. As one board member concluded, "We have developed a special niche within the community college system."

Board members viewed the president as effective in influencing board members in their directing of the college, including the maintenance of its public image. Whereas board members saw the president as a policy initiator, and public image perpetuator, the president indicated that it was tradition and institutional culture which were promoted and maintained. Board members, too, acknowledged the pervasiveness of a clearly identifiable institutional culture which valued intellect, debate, and correctness, and generated high standards for both its members and clients. Through the actions of the president, this institutional culture was nurtured and preserved.

\section{Comparative Analysis: Three College Presidents}

At each of the three colleges, the president had influence and impact upon the institution, albeit for distinct reasons and in specific areas. At Appletree College, the most pronounced areas of presidential involvement were in the creation and maintenance of a public image for the college, and in government 
relations. The president's personal relationship with the government minister responsible for colleges and the president's actions in improving the image of the college in the local community had, in the words of board members, made an impact on how the college functioned. As one board member noted, the president was the "right person at the right time."

At Oak College, the president was most actively involved in the areas of policy development and in the promotion of the public image of the college. The president was judged to make a difference in institutional functioning, by promoting and maintaining a participatory style of decision-making among college constituents, in motivating board members to serve the college as volunteers, and by sustaining an esprit de corps among college personnel. As one board member noted, the president "personalizes the mission of the college" as if "his love for the college is transferred" to others.

At Cedar College, the president was most active in the areas of policy development and in the promotion and maintenance of a public image for the college, both within the college and in the community. By promoting and adhering to the college's philosophy, the president maintained the status quo of the college. The president had influence in the functioning of the college as a consequence of his intellectual abilities and by being, as one board member noted, an "artful negotiator."

At all three colleges, the president was seen by board members as influential in the functioning of the institution. Presidents were seen to have involvement and influence in the areas of policy development, the creation and promotion of a public image for the college, and, in one case, with governmental relations. Presidents were not viewed as heavily involved or influential in the development and allocation of budgets or in the establishment of internal harmony among college constituents. Moderate involvement was accorded to presidents in the area of educational planning.

Each president had special abilities or traits. At Appletree College, the president possessed the attributes of achieving rapport with others, of projecting trustworthiness, and exhibiting attractive personal principles and goals. At Oak College, the president reflected values which corresponded closely to those held by board members, in his actions as facilitator of participatory decision-making and in his personal approach to management of the college. At Cedar College, the president's skills as thinker and negotiator brought him considerable power to influence others. He was seen to use his personal abilities and the authority of his institutional position effectively. 
At all three colleges, the president was seen by board members as the institution's leader. Nonetheless, the responses from board members did not indicate that the president's leadership role had an impact on educational functioning. No specific educational initiatives, such as a particular program, were associated with the president. No policies related to student learning were associated with the president. No actions or decisions pertaining to teaching performance of faculty were connected to the president. Instead, the educational role of the president had two faces. Once face was the president as communicator of educational plans and actions to college constituents, to the public, and to government. The second face was the president as educator of the college board in the ways of the institution and in the issues facing the college, internally and externally.

\section{Discussion}

In "The Nature of Administrative Behavior in Higher Education," Dill (1984) offers three observations relevant to the present study. First, he notes that "informal influence, negotiations, and networks of contacts are important aspects of academic administration" (Dill, 1984, p. 92). Second, he observes that academic management is susceptible to influence by interest groups, this influence being largely political. And third, he indicates that "the traditions, beliefs, and values of individuals, disciplines, and institutions" (Dill, 1984, p. 92) have a substantial role in academic management. The evidence from this study supports and illuminates these observations.

In the descriptions of board members, the three presidents in this study were characterized by their attributes, behaviours, and actions, suggesting networking, negotiating, and influencing. In rather distinct ways, the presidents coped with or accommodated interest groups. At Appletree College, the president befriended the Minister of Advanced Education and Job Training. At Oak College, the president encouraged the involvement and influence of the faculty in decision-making. And at Cedar College, the president adopted the traditional values of the college, adhered to by the college's most influential interest group, the faculty. It should be clear from the discussions of Oak and Cedar colleges that the presidents incorporated the traditions and values of the institution in their management approaches: in decision-making at Oak College and in promoting and respecting particular values at Cedar College. At Appletree College, the president promoted what both he and the board regarded as necessary goals and values for the institution. These included an improved reputation for the college and a personally responsive, client-oriented, approach to operations, especially with respect to the external environment. Given the negative 
reactions in the past on the part of college constituents, as reported by board members, institutional traditions and long-held beliefs may have diminished or vanished at Appletree College. Thus, the actions of the president (e.g., altering administrative structure, personal involvement in local community events and organizations) could have initiated the development of traditions and beliefs for college constituents. Whereas the other two presidents were seen as the maintainers of beliefs, traditions, and values, the president at Appletree College may have been engaged in their creation and establishment.

The two faces of the president, noted above, as communicator of college plans and actions, and as educator of the governing board, associate the president with institutional functioning. The application of Dill's (1984) observations on administrative behaviours to this study suggests that the three presidents were able to address those areas of significance in academic management. Identified as institutional leaders, the presidents not only communicated plans and actions to college constituents, to the public, and to government, but also were identified with those plans and actions. Thus the image of the college, and the college itself in its intentions, behaviours, and actions, as perceived by college constituents, the public and government was, if not the creation of the president, at least the responsibility of the president. Here, the messenger would be seen as synonymous with the message. What the president did, therefore, as policy developer or community organization participant, had, in the perception of others, a connection with institutional performance.

Whetten and Cameron (1985) note that the "research on organizational effectiveness in higher education has generated a list of eight characteristics of effective administrators" (Whetten \& Cameron, 1985, p. 36) which they refer to as "eight fundamental principles of administration" (Whetten \& Cameron, 1985, p. 37). There is an assumption here that administrators can be effective and that there is a connection between administrative behaviours and organizational functioning. Of the eight principles identified by Whetten and Cameron (1985), most apply to the three presidents in this study. Two of these are discussed for illustrative purposes. One of these principles is that an effective administrator places as much emphasis upon process as upon outcomes. The three presidents in this study were seen to emphasize process as much as outcomes. At Appletree College, the president altered the administrative structure of the college, in part to provide greater opportunity for internal college constituents to participate in institutional decisions, and in part to involve administrators more fully in the management of the college. While the president of Appletree College, more so than the other two presidents, was able to produce outcomes, 
his team approach to management suggests that process was as important as outcomes. At Oak College, the president emphasized process in preference to outcomes. His behaviours with respect to decision-making, his behaviours with the board, his actions in managing the college, and the paucity of outcomes identified by board members, suggest that management and governance were approached by the president as processes, or vehicles, to encourage the development of a college community combining the internal college constituents and the external community. At Cedar College, the president's emphasis on processes was an adherence to the traditional ways in which the college operated. Process not only reinforced tradition and institutional values, but also followed traditions and values. The assumption at Cedar College was that, if processes are compatible with traditions and values, then outcomes will be those anticipated and sought.

Another principle of effective administration is "successful coalition management" (Whetten \& Cameron, 1985, p. 39). Moreover, effective administrators demonstrate three characteristics: "they are politically astute, pragmatic, and skillful bargainers" (Whetten \& Cameron, 1985, p. 39). The presidents at Appletree, Oak, and Cedar colleges amply demonstrated these characteristics to their governing board members. The primary characterization of the president at Appletree College suggested an individual with more than ordinary interpersonal and political skills; his abilities produced both broad and deep support for his actions and his leadership, especially from the board itself, as well as from community members and from government officials. The president at Oak College cultivated personal support through exhibiting a personal and passionate commitment and dedication to his college. This gained him the support of college constituents and community members, and the strong support from the governing board which viewed the president and the institution as inseparable. Furthermore, the president's promotion of participation in decision-making among college constituents, in the view of board members, brought internal support to the president and reinforced a participatory style of management and governance. At Cedar College, the president was referred to as an "artful negotiator," and this view was supported by other descriptions made by board members. The president used his negotiation and political skills to maintain the college philosophy and to further the view and vision he had of the college as an elite institution.

From the perspective provided by Whetten and Cameron (1985), the three presidents exhibited characteristics of effective administrators and these administrators were seen as determinants of institutional performance. Whetten and 
Cameron (1985) note that traditional standards and notions about effectiveness, which rely on indicators such as public perception about the value of academic credentials, increasing institutional enrolments, and efficiency are dependent upon external environmental forces, outside the control of administrators. These are not, according to Whetten and Cameron (1985), legitimate indicators of administrative effectiveness.

\section{The Paradox of the Presidency}

It is not evident from this study whether or to what extent the three presidents were effective in areas addressed by traditional indicators of effectiveness, such as student enrolments or institutional efficiency. It is also not evident whether the three presidents were effective in the area of student learning or student performance or in the area of college faculty teaching development. None of these was referred to by either board members or presidents as outcomes of presidential behaviours and actions. This may be a consequence of the questions put to the respondents. Nonetheless, according to other indicators of administrative effectiveness, such as the management of political groups, the accommodation of institutional traditions and beliefs, and the emphasis on process, especially in decision-making, the three presidents can be seen to have had both influence and impact on institutional functioning. It is likely, therefore, that the connection between what a president does and institutional performance depends upon the kinds of outcomes which are examined. Human behaviours, institutional traditions and values, and the public image of the college are far different indicators of institutional effectiveness (and thus presidential impact) than are student enrolments, financial efficiency, and student performance. It may be that, with these latter indicators of effectiveness, the president does not have impact, while with the former ones, the president has, according to this study, substantial impact. This situation may suggest that there is a paradox associated with presidential influence. That is, the president in some significant areas does have influence and impact on institutional functioning and in other areas has both personal limitations and external and internal environmental constraints which impede or frustrate influence or impact. The president both does and does not make a difference.

Perhaps it is time for scholarship to move beyond the division so evident in mainstream thinking on the presidency at higher education institutions. The exaggerated view of the promethean figure who is a college or university president is juxtaposed to a diminished perspective of human inadequacy and impotence. By accepting the paradox of the presidency, scholars and practitioners 
can both discard the expectations of the presidency and the judgments and appeals for improvement, which accompany presidential failure to meet these expectations, and replace these with more realistic and locally derived perceptions and responses. Both ways of thinking could be set aside so that they do not mask what could be detected in the examination of presidential behaviours and institutional performance.

\section{Conclusions From This Study}

The assessment of presidents at three community colleges by governing board members indicates that presidents have both influence and impact upon institutional functioning. The behaviours of these administrators were consistent with the observations of Dill (1984) who identifies significant areas of influence for academic administrators. The characteristics of the three presidents were also consistent with the characteristics of effective administrators noted by Whetten and Cameron (1985). Thus, not only in the views of board members at the three colleges did the presidents make a difference in institutional functioning, but also on the basis of the criteria identified by scholars can the presidents be seen as influential and effective. It may be because of both their formal and informal relationship with the president that board members are able to identify the connection between the president and institutional functioning whereas, according to Birnbaum (1989), faculty are not able to make this connection. It is also apparent that what the board members at these three colleges perceived as presidential behaviours and actions, as well as outcomes of these, was closely aligned with the areas of significance noted by Dill (1984) and the indicators of effectiveness identified by Whetten and Cameron (1985).

Cameron (1978) argues that organizational effectiveness, especially in higher education institutions, is not a unitary concept. In particular, he notes that different constituencies have various viewpoints on what criteria indicate effectiveness. Also, he suggests that a focus on organizational attributes rather than on operational goals can lead to improved analysis of effectiveness. In this present study, the constituents were members of the governing board. In light of their institutional position, their relationship with the president, and their own specific interests, it should not be surprising that their assessment of presidential influence would differ from that derived from other constituents such as faculty (see Birnbaum, 1989). It is also apparent that their criteria for presidential influence and impact on the institution were similar to criteria put forward by scholars (e.g., Dill, 1984; Whetten \& Cameron, 1985) on significant areas of academic management and on effective administrative behaviours. 
This study concludes that, from the perspective of board members at three community colleges, presidents do make a difference in institutional functioning. Presidential impact was seen in public and government perceptions of the college, in institutional decision-making, and in the preservation of college philosophy. Furthermore, the president was seen as an educational leader - not as a determiner of educational programs or teaching performance of faculty, but rather as the communicator of institutional directions and actions and as an educator of the institution's formally designated governors, the members of the board.

\section{References}

Benzet, L., Katz, J., \& Magnusson, F. (1981). Style and substance. Leadership and the college presidency. Washington, D.C.: American Council on Education.

Birnbaum, R. (1989). Presidential succession and institutional functioning in higher education. Journal of Higher Education, 60, 123-135.

Bimbaum, R. (1988). How colleges work. San Francisco: Jossey-Bass Publishers.

Cameron, K. (1978). Measuring organizational effectiveness in institutions of higher education. Administrative Science Quarterly, 23, 604-629.

Cohen, M., \& March, J. (1986). Leadership and ambiguity: The American college president. Boston: Harvard Business School Press.

Dennison, J., \& Gallagher, P. (1986). Canada's community colleges. Vancouver, B.C.: University of British Columbia Press.

Dill, D. (1984). The nature of administrative behavior in higher education. Education Administration Quarterly, 20, 69-99.

Dodds, H. (1962). The academic president - Educator or caretaker? New York: McGraw-Hill Book Company.

Fisher, J. (1984). Power of the presidency. New York: MacMillan Publishing Company.

Kauffman, J. (1980). At the pleasure of the board. Washington, D.C.: American Council on Education.

Kerr, C., \& Gade, M. (1986). The many lives of academic presidents. Washington, D.C.: Association of Governing Boards of Universitics and Colleges.

Levin, J. (1989). The board-president relationship in three community colleges. Unpublished doctoral dissertation, University of British Columbia.

Miles, M., \& Huberman, A. (1984). Qualitative data analysis: A sourcebook of new methods. Beverly Hills, CA: Sage Publications.

Mortimer, K., \& McConnell, T. (1978). Sharing authority effectively. San Francisco: Jossey-Bass Publishers.

Pfeffer, J. (1981). Management as symbolic action: The creation and maintenance of organizational paradigms. Research in organizational behaviour, 3, 1-52. 
Stoke, H. (1959). The American college president. New York: Harper and Brothers.

Vaughan, G. (1986). The community college president. New York: American Council on Education and MacMillan Publishing.

Whetten, D., \& Cameron, K. (1985). Administrative effectiveness in higher education. The Review of Higher Education, 9, 35-49.

Wood, M. (1985). Trusteeship in the private college. Baltimore: The Johns Hopkins University Press. 